\title{
Intervention and Non-Intervention in Classical International Political Theory: Immanuel Kant and J.S. Mill
}

\begin{abstract}
Alexis Heraclides
Abstract: This article examines the intervention/non-intervention nexus which has confounded scholars and diplomats ever since its inception in the eighteenth century. Seven positions on non-intervention/intervention in the long nineteenth century are presented and compared with seven quasi-similar present-day positions. Then classical international political theory in the long nineteenth century is briefly broached on the basis of the dichotomy between cosmopolitanism and communitarianism. Kant's stance on the question is examined in detail, from his own restricted non-intervention premise which permits for only one exception, to the view of Kantian scholars, several of which tend to regard Kant as more open towards exceptions to intervention, including humanitarian intervention. J.S. Mill is far more detailed on the matter. Five arguments on the part of Mill are identified in favour of non-intervention, especially if the internal war is against 'native tyrants' (where it is better to save themselves without 'foreign bayonets'); and five arguments as exceptions to intervention, including struggles against foreign rule, counter-intervention and intervention for humanitarian reasons. The article concludes by pinpointing the lasting contributions of Kant and Mill on the subject discussed that are also of relevance in today's world society.
\end{abstract}

Keywords: intervention, non-intervention, humanitarian intervention, protracted civil wars, national war of liberation, counter-intervention

\section{INTRODUCTION}

The intervention/non-intervention nexus, with significant theoretical and practical consequences in international politics and international law, has confounded scholars and diplomats ever since its inception in the eighteenth century. To begin with, contrary to a widely-held belief, previously in the Peace Treaty of Westphalia (1648), non-intervention is not mentioned at all ${ }^{1}$ nor is sovereignty for that matter. ${ }^{2}$ And intervention as a legal concept was not covered by the founding fathers of international law in the sixteenth and seventeenth centuries (Vitoria, Suarez, Gentili and Grotius) whose approach regarding armed violence was the 'just war doctrine'. Non-intervention/noninterference and intervention/interference appeared in the first part of the eighteenth century, mainly in the work of Christian Wolff (who is associated with absolute non-interference) ${ }^{3}$ and Emer de Vattel. $^{4}$

In the long nineteenth century that will preoccupy us in this article, 'intervention' (originally a French term) or 'interference' (the main term used by Britain until mid-century) was 'Protean', covering an array of manifestations 'from a speech in Parliament by Palmerston to the partition of Poland'.

The Argentinean diplomat and jurist Carlos Calvo, in his acclaimed 1870 treatise points out that on intervention 'there are almost as many opinions as there are authors. Some admit it, approving intervention; others condemn it, repudiating it; for some it has become a right, others add the idea of duty; others see nothing else but a simple fact, a brutal fact, which has its place in history...' 6

The situation remained unresolved well into the twentieth century. As Percy Winfield put it in his survey of intervention in the early 1920s: 'The subject of intervention is one of the vaguest branches of international law. We are told that intervention is a right; that it is a crime; that it is the rule; that it is the exception; that it is never permissible at all' ${ }^{7}$ The problem with intervention continued following the Second World War in international law as well as international relations. ${ }^{8}$ In the postCold War era, with its increased interventionism, interest has hardly lapsed, ${ }^{9}$ the main focus now being on 'humanitarian intervention' in situations of protracted internal wars or in other instances where widespread egregious crimes are being committed or threatened. The relevant literature from 1990 until today has produced almost a hundred volumes. ${ }^{10}$ 
But two things are clear. Intervention meant then - and today ${ }^{11}$ - 'coercive', 'dictatorial interference by a State in the affairs of another State for the purpose of maintaining or altering the actual conditions of things'. ${ }^{12}$ Moreover, non-intervention was - and is - the rule, intervention the exception. ${ }^{13}$

\section{NON-INTERVENTION/INTERVENTION IN THE LONG NINETEENTH CENTURY}

In the course of the long nineteenth century, no less than seven positions on non-intervention /intervention can be discerned in international diplomatic practice, international law and international political theory: (1) strict adherence to non-intervention; (2) exceptions limited to instances of threats to vital national interests, a position taken at the diplomatic level by Castlereagh, Chateaubriand and Guizot as foreign ministers, which could include threats to - or the upsetting of - the balance of power (an exception to non-intervention which goes back to Vattel ${ }^{14}$ ); (3) the exception being intervention to save a legitimate government from a revolt (the standard stance of Metternich); (4) the exception to non-intervention limited to protracted civil wars in which a state has collapsed into total anarchy, with two or more entities claiming sovereign rule (Kant); (5) the main exception being to assist a national liberation movement struggling for freedom against alien rule which is danger of being crushed by its militarily mightier opponent (John Stuart Mill); (6) exceptions to include humanitarian reasons, what came to be known as humanitarian intervention (the stance of the majority of international jurists at the time); and (7) such interventions to be limited only to humanitarian interventions of so called 'civilized' states against 'barbarian' states.

If one was to compare these seven position with the problematique from 1971 (Bangladesh) onwards, one finds, mutatis mutandis, similar positions (see just below). The only clear variance is the above $7^{\text {th }}$ position which is totally unacceptable today and interestingly it was also under attack by many (though not all) the international jurists in the nineteenth century and until 1914, especially with reference to intervening for humanitarian reasons, during the long nineteenth century. ${ }^{15}$

The state of play in the literature and in practical international politics of the last forty years is more or less the following: (1) strict adherence to non-intervention, especially by scholars and officials in Asia and Africa, at times with the addition of the cultural relativism thesis (especially in relation to human rights, democracy, government, legitimacy and others); (2) exceptions limited to instances of threats to vital national interests (the position of Morgenthau, Kissinger and most traditional realist IR scholars); (3) intervention to save an incumbent government if it has requested foreign military intervention (as in the case of the Bosnian appeals in the early 1990s), which in international law does not amount to intervention at all; (4) interventions in protracted civil wars or in situations where a state has collapsed into total anarchy, as in the case of Somalia (a thesis adopted by most liberal IR scholars); (5) secessionist self-determination, particularly those in which a community or society suffers and experiences acute discrimination akin to 'internal colonialism' within a state (what has been called 'remedial secession') though some are more lenient, regarding the will of the nation or ethnic, religious or racial group for 'exit' crucial and not its suffering and acute discrimination as a necessary precondition; (6) humanitarian intervention or intervention on the basis of the 2005 principle of Responsibility to Protect (RtoP or R2P), in instances of massive outrage, such genocide, crimes against humanity, war crimes or ethnic cleansing (although others are more flexible as to the crimes committed, limiting them to discrimination, racial, ethnic, religious or otherwise); and (7) exceptions to include military and other tangible assistance primarily to organizations and people struggling against flagrant forms of racism, especially if committed by minority against a majority of the population (as with apartheid South Africa), a situation which also amounts to a flagrant violation of the internal dimension of the principle of self-determination (majority rule).

But let us return to the long nineteenth century. As regards internal wars (civil wars and wars of national liberation) one approach for states was the cordon sanitaire line, namely the sealing off the state experiencing civil war and thus avoiding getting into a messy situation with unpredictable results, ${ }^{16}$ which has also been applied in many instances from 1945 until today. But absolute noninvolvement or an embargo on arms (as seen in the 1990s with the Bosnian tragedy) could inadvertently amount to supporting the militarily more powerful party in an internal war, allowing it to crush its adversary. To remember a famous Talleyrand adage: non-intervention ' $[c]$ 'est un mot métaphysique, et politique, qui signifie à peu pres la même chose qu'intervention' ${ }^{17}$

In the nineteenth century a new concept known as 'belligerency' was installed and applied, whereby a foreign government could recognize insurgents as 'belligerents' in instances where an internal war in another country was prolonged and deadly and if a number of criteria were met, the so called 'factual test' (the insurgents occupying and administering a large portion of a state's territory and others). ${ }^{18}$ 
Recognition of belligerent status (or belligerency) was a matter of discretion on the part of states and did not imply diplomatic support to the insurgent party. ${ }^{19}$ Yet it was more often than not seen as an unfriendly act by the incumbent government and the insurgents for their part tended to regard it as a form of moral encouragement to their cause, as seen with Canning's recognition of Greek belligerency in $1823,3^{20}$ and the contrary, withholding belligerent status when it seemed warranted, was seen as an unfriendly act by the insurgents, as seen in the US-Cuban case in 1895-98, with Washington withhold recognizing belligerent status for the Cuban freedom fighters even when it opted for an all out war against Spain that as a consequence would have liberated Cuba from Spanish rule. $^{21}$

\section{International Political Theory}

Contrary to international law which during the long nineteenth century (1789-1914) focused on nonintervention/intervention and especially on humanitarian intervention as a possible acceptable exception to non-intervention (which led to a considerable debate among the majority of international jurists), ${ }^{22}$ international political theory and political philosophy paid scant attention during the same period to the ethics of intervention. ${ }^{23}$ Among the few that took a position on the matter (though rarely in detail as the jurists) are Immanuel Kant, Georg Hegel, Jeremy Bentham, Richard Cobden and in particular John Stuart Mill, the only one to present a detailed argumentation on non intervention as well as intervention.

Based on the present-day dichotomy between cosmopolitanism and communitarianism one would expect that the cosmopolitans of those days would be inclined towards intervention for humanitarian or other ethical or principled reasons (such as assisting national self-determination), and communitarians would have adhered to non-intervention. ${ }^{24}$ Yet Kant, the father of modern cosmopolitanism was (as we shall see) prima facie against intervention; the same is the case with another great cosmopolitan, Bentham, who was also an ardent pacifist and anti-colonialist, ${ }^{25}$ and with Cobden, a clear cosmopolitan and pacifist ${ }^{26}$ who was rigidly against any notion of intervention. ${ }^{27}$ Mill, arguably a communitarian, ${ }^{28}$ places himself (as we shall see) gingerly between non-intervention and intervention. Only Hegel, perhaps the father of the communitarian approach, ${ }^{29}$ does not defy expectations, advocating non-intervention 'even when it is undertaken for benign purposes'.

We will consider the views of Immanuel Kant and John Stuart Mill on non intervention/intervention given their wide influence and the debate their views have generated which remains relevant until today.

\subsection{Kant}

Immanuel Kant, the quintessential cosmopolitan of his age, ${ }^{31}$ at least by the then standards, ${ }^{32}$ the advocate of a peaceful confederation of republican states and of universal human rights, ${ }^{33}$ has very little to say about intervention and does not refer at all to intervention for humanitarian or other ethical reasons.

Kant in Preliminary Article 5 of his celebrated essay, Toward Perpetual Peace. A Philosophical Sketch (1795), ${ }^{34}$ states that 'No State Shall by Force Interfere with the Constitution or Government of Another State'. And he makes two points: (a) that who is to authorize interference, implying that there is no higher authority; and (b) if a state has fallen into 'evil', 'its lawlessness should serve as a warning, ${ }^{35}$ And he comes up with only one exception to non-intervention: ${ }^{36}$

if a state, through internal discord, should split into two parts, each ...laying claim to the whole; in that case a foreign state could not be charged with interfering in the constitution of another state if it gave assistance to one of them (for this is anarchy).

He then cautions that prior to this critical phase, such interference would amount to 'a violation of the right of a people' making 'the autonomy of all states insecure' ${ }^{37}$ Only when a state has collapsed into anarchy, with rival groups claiming sovereign authority, can other states intervene to assist in bringing about an end to the anarchy. ${ }^{38}$

Surprisingly Kant (like Grotius) was opposed to revolution against oppression, ${ }^{39}$ despite his enthusiasm for the French Revolution, the American Revolution and the Irish struggle, a contradictory position that has baffled scholars ever since. ${ }^{40}$ 
Kant does not address intervention in any other work and it is clear that he does not suggest any right or duty of humanitarian intervention ${ }^{41}$ or intervention to promote 'republicanism' ${ }^{42}$ His position on intervention is not unrelated to his position on war. For the German philosopher, war is 'the scourge of mankind', 'the destroyer of everything good ${ }^{43}$ and 'creates more evil than it destroys'. ${ }^{44}$ Yet strictly speaking he was not a pacifist. ${ }^{45} \mathrm{He}$ was critical of 'a long peace' in some cases ${ }^{46}$ and regarded the historical emergence of civil society the result of violent means and war, which unified people under a general will. ${ }^{47}$ On the whole a justified war was defensive: to defend one's country and repulse aggression, including 'anticipatory attack' ${ }^{48}$ But as regards military intervention he was more than clear: intervention even for ethical reasons introduces a right to war, with a disastrous effect in the attempts to ban war. ${ }^{49}$

One group of scholars based on the clear prohibition of Preliminary Article 5 claim that Kant upholds a fairly rigid principle of non-intervention ${ }^{50}$ But others have expressed the view that he did not reject intervention outright, especially humanitarian intervention. The latter approach can be divided into two groups, those who claim, in a rather hesitant and circumspect manner, that had Kant been faced with massacres and other atrocities, akin to genocide (such as, I would say, the onslaught of the West Pakistanis under General Tikka Khan in East Pakistan in 1971 with its resultant 'mountain of corpses' as put by Tajuddin Ahmed, the Prime Minister of the Bangladesh government-in exile, or the more recent Rwanda genocide) he would probably have been more open to intervention for humanitarian reasons,${ }^{51}$ and there are those who claim that he was in fact supportive of humanitarian intervention. ${ }^{52}$

One line of reasoning is to link Preliminary Article 5 with Kant's First Definite Article which reads as follows: 'The Civil Constitution of Every State shall be Republican'. Republican states are peaceful internationally and base their internal policy on justice, rule of law and respect for individual autonomy ${ }^{53}$ From this perspective it has been argued that, assuming that the definite articles are 'more basic' (in fact this is not the case) non-intervention 'does not apply to forms of intervention that might promote or defend the development or survival of republican forms of government'.${ }^{54}$

R.J. Vincent for instance was of the view that 'Kant appeared to imply an exception to the rule of nonintervention if by intervention a republic could be established or a despotic regime crushed', 55 Along similar lines Fernando Tesón argues that Kant's 'nonintervention principle is dependent upon compliance with the First Definitive Article. Internal legitimacy based on respect for human rights and democracy is what gives states the shield of sovereignty against foreign intervention'. ${ }^{56}$ Consequently 'nonintervention holds only among liberal states'. ${ }^{57}$ Harry van der Linden refers to Kant's concept of states as 'moral persons with autonomy' founded on 'the social contract' and 'united will'. On this basis he surmises that 'that political intervention is only wrong with respect to republican states, or approximations thereof, and may be justified with regard to unjust states if it accords with the will of their people struggling for democracy, ${ }^{58}$

Other Kantian scholars venture into more contentious grounds. Thomas Hill for instance maintains that according to Kant's logic people in anarchy or 'a state of nature' can be forcefully made to join the legal order 'so long as it is reasonably certain that intervention is necessary and will be effective without further implications and effects that are morally unacceptable' [emphasis in the original] ${ }^{59}$ and concludes that in Kant's ethics 'there is no absolute prohibition of humanitarian intervention in all cases'. ${ }^{60}$ Antonio Franceschet admits that Kant has nothing explicit to say on humanitarian intervention, ${ }^{61}$ but argues that one can extrapolate from his work, if it is seen from its 'ethico-political reasoning within his broad roadmap for international reform' and 'legal evolution' ${ }^{62}$ and points to five themes in Kant to buttress his view regarding the philosopher's advocacy of humanitarian intervention: (1) juridical pacifism; (2) institutionalisation and constitutionalisation; (3) the restructuring of the rights of war and peace; (4) the development of authorised coercion; and (5) cosmopolitan citizenship rights. ${ }^{63}$

It is hard to pass judgment whether these authors interpret Kant correctly or present a different Kantian perspective and not Kant as such (I suspect that the latter is the case, but not being a Kantian scholar my view is hardly authoritative). As for Preliminary Article 5 being applicable only to republican states, in fact only the definite articles refer exclusively to republican states; the preliminary articles refer to all states, republican or otherwise; ${ }^{64}$ and Kant "nowhere makes any explicit claim regarding the priority of republicanism over nonintervention, ${ }^{65}$ More generally, Kant wanted to deter states becoming paternalistic guardians of the well-being of other states. ${ }^{66}$ 
To conclude, Kant was guarded on intervention, not wanting to open a Pandora box for various forms of armed or other interventions, given his views on war and peace, autonomy and morality. He wrote Perpetual Peace in the wake of the French Revolution and apparently one of his aims was not to give grounds for foreign interventions against the Revolution ${ }^{67}$ (as advocated, say, by Edmund Burke ${ }^{68}$ ). Furthermore, Kant as a cosmopolitan was not an advocate of conquest and colonialism (especially in his mature years), to bring in the less fortunate non-Europeans in the European fold. ${ }^{69}$ But even scholars critical of the extrapolations of others, are prepared to offer a small opening for intervention in extreme humanitarian cases. Pierre Laberge for instance is of the view that "[s]ince genocide is an idea that can scarcely have occurred to him, to hold that he would prohibit intervention even in such extreme circumstances is surely to be guilty of an anachronism'. ${ }^{70}$ Georg Cavallar is prepared to entertain that 'Kant might have favoured intervention to stop dramatic violations of human rights (for example genocide), ${ }^{71}$ Franceschet is predictably more forthright: 'The idea that a state that would commit or allow genocide or would otherwise deny its population their basic moral rights or humanity is not only inconceivable but conceptually impossible for Kant ${ }^{72}{ }^{72}$ Howard Williams acknowledges the opening that may arise from Kant's support for universal human rights and 'a moral responsibility to be concerned about how citizens in other states are treated by their governments', ${ }^{73}$ but asserts that this does not lead to 'active involvement of our government in attempting to redress or punish wrongs in other states' ${ }^{74}$ His conclusion is that only 'the breakdown of order' tantamount to civil war, with no sovereign power in control permits intervention and provided it has been requested by one of the warring sides, notably 'the party that would bring the disputed territory into the peaceful federation' ${ }^{75}$

\subsection{J.S. Mill}

John Stuart Mill is classified today as a communitarian, especially given his stance on nationalism and national liberation. ${ }^{76}$ But if one takes into consideration other aspects of Mill's approach to international relations, such as his emphasis on 'the general prosperity of mankind' or international law as the protector of the weak, ${ }^{77}$ he appears more of a cosmopolitan or simply defies classification. ${ }^{78}$

Mill's main work on non-intervention/intervention is a famous 1859 essay, entitled 'A Few Words on Non-Intervention', ${ }^{79}$ published in Fraser's Magazine, where he makes a very strong case for nonintervention but an equally convincing case for intervention under several circumstances. This has led to confusion as to where he really stands and he has been criticized as 'ambivalent', ${ }^{80}$ and 'not at his most convincing ${ }^{81}$ regarding the principle (non-intervention) he presumably, judging from the title, set out to defend.

Reference to intervention is also made by Mill in an earlier paper, 'The French Revolution of 1848 and Its Assailants', published in The Westminster and Foreign Quarterly Review (April 1849) (a journal Mill edited together with John Bowring), which is better known as 'Vindication of the French Revolution of February $1848^{\prime} .^{82}$ In this polemical text, in which he defends Lamartine's stance (the Romantic poet had become French foreign minister in 1848) in support of intervention 'to assist any nation which might be struggling to free itself from the yoke of foreign conquerors', ${ }^{83}$ Mill clearly opts for intervention. This also applies to an earlier forgotten article, 'The Spanish Question', whose authors are not mentioned, written eleven years before in The London and Westminster Review (July 1837), which Mill had written jointly with a former army officer with Spanish experience. ${ }^{84}$

The main criterion to make sense of Mill's overall position on non-intervention/intervention is whether a movement seeking freedom is seeking independence from 'a foreign yoke' or is seeking to overthrow a 'native tyrant' (although the two distinct cases are not always clear as day in his writings). In the first instance Mill advocates external intervention (as we shall see, starkly, hesitantly or on the condition of prior intervention in support of the incumbent government), while in the second he advocates strict non-intervention, ${ }^{85}$ for he regards external intervention as counter-productive and detrimental to the cause of freedom (the search for a liberal constitution and free democratic rule) ${ }^{86}$

Let us start with non-intervention. Mill was opposed to intervention in support of liberty, for a people will be better served if they 'are left to work out their own salvation' ${ }^{87}$ At least five arguments can be identified in support of non-intervention on his part. ${ }^{88}$

The first argument is uncertainty as to the outcome of intervention. According to Mill 'there can seldom be anything approaching to assurance that intervention, even if successful, would be for the good of the people themselves' ${ }^{89}$ The second argument is the readiness to wage a struggle despite the 
grave dangers involved. As he puts it: 'The only test possessing any real value , of a people's having become fit for popular institutions, is that they ... are willing to brave labour and danger for their liberation'. ${ }^{90}$

This is related to the argument of authenticity. ${ }^{91} \mathrm{He}$ asserts 'if they have not sufficient love of liberty to be able to wrest it from merely domestic oppressors, the liberty which is bestowed on them by other hands than their own, will have nothing real, nothing permanent'. ${ }^{92}$ In 'The Spanish Question' he puts it thus: 'The attempt to establish freedom by foreign bayonets is a solecism in terms. A government which requires the support of foreign armies cannot be a free government'. ${ }^{93}$

This leads us to a fourth argument, the danger of reversal to tyranny again linked to one's own fighting. He argues that '[i]f a people ... does not value it [freedom] sufficiently to fight for it, and maintain it against any force which can be mustered ... it is only a question in how few years or months that people will be enslaved'. ${ }^{94}$

A related fifth point is that the virtues and feelings needed 'for maintaining freedom' spring up only 'during an arduous struggle to become free by their own efforts' ${ }^{95}$ In this context he makes a telling point: 'Men become attached to that which they have long fought for and made sacrifices for; they learn to appreciate that on which their thoughts have been much engaged...' ${ }^{96}$ This considerable insight on the part of the utilitarian philosopher tallies with the findings of today's cognitive psychology. As Leon Festinger had put it: 'Rats and people come to love the things for which they have suffered' ${ }^{97}$ This is the case, according to Morton Deutsch, presumably 'in order to reduce the dissonance induced by the suffering, and their method of dissonance- reduction is to enhance the attractiveness of the choice which led to their suffering: only if what one chose was really worthwhile would all of the associated suffering be tolerable'. ${ }^{98}$

The emphasis of Mill on a people's ability to use force successfully for liberation has been criticized as a social Darwinian (actually crude Spencerian ${ }^{99}$ ) 'survival of the fittest ${ }^{100}$ even though Mill was not a social Darwinist. Walzer claims that this accusation, though not wide off the mark, is unfair to Mill 'for it was precisely Mill's point that force could not prevail, unless it was reinforced from the outside over a people ready "to brave labor and danger'. ${ }^{101}$ Anthony Ellis attributes Mill's stance on his belief 'that a people will be hard to oppress for long, once they have set their minds on freedom? ${ }^{102}$

Now let us present the other side of the coin, intervention. Commentators have identified various exceptions to non-intervention, based mainly on 'A Few Words', but despite some common ground there is also disagreement, the exceptions to non-intervention ranging from only two (in the case of Michael Walzer's early assessment) to as many as seven (by Michael Doyle) (see Table I). My reading of all three essays (in what is often an unclear or convoluted presentation on the part of Mill) has led me to the conclusion that he argues for five exceptions to non-intervention: ${ }^{103}$ (1) in relations with 'barbarians', (2) for defensive purposes in dealing with 'barbarous' and/or aggressive neighbors, (3) in struggles against a foreign yoke, (4) in order to offset a previous intervention by an external party against a people fighting for freedom against foreign rule, what is known as counter-intervention and (5) in protracted civil wars in order to stop 'severities repugnant to humanity', that is humanitarian intervention.

Mill subscribed to the famous nineteenth century threesome distinction of civilized states (or nations), 'barbarous' states (or nations) and 'savages' ${ }^{104}$ (which has its origins in Montesquieu's The Spirit of the Laws) ${ }^{105}$ and also to another variant, the binary distinction between 'civilized' and 'barbarian' (or 'barbarous' or 'uncivilized') nations (seen in Wolff), or 'civilized' and 'savages' (seen in Adam Smith and Kant). Mill tends to lump 'barbarians' with 'savages'. ${ }^{106}$ Under 'barbarians' per se, he includes the Hindus, as a whole or with special reference to the Indian principalities, notably the Awadh, which he calls 'semi-barbarians', given their ancient culture but 'stationary for many ages'. ${ }^{107}$ Mill believed that a civilization at some historical point could become stagnant, as in the case of the ancient Egyptians and in his days with the Indians and the Chinese. ${ }^{108}$

For Mill 'civilized nations' owe no duty to respect the independence of 'barbarous' nations. As he puts it: 'The sacred duties which civilized nations owe to the independence and nationality of each other, are not binding towards those to whom nationality and independence are either a certain evil, or at best a questionable good'. ${ }^{109}$ He provides two reasons to buttress this point: firstly 'the rules of ordinary international morality imply reciprocity. But barbarians will not reciprocate. They cannot be 
depended on for observing any rules. Their minds are not capable of so great an effort, nor their will sufficiently under the influence of distant motives'; ${ }^{110}$ and secondly 'nations which are still barbarous have not got beyond the period during which it is likely to be for their benefit that they should be conquered and held in subjection by foreigners'. ${ }^{111}$ And he adds: 'The Romans were not the most clean-handed of conquerors, yet would it have been better for Gaul and Spain, Numidia and Dacia, never to have formed part of the Roman Empire?' ${ }^{112}$ For Mill 'barbarians have no rights as a nation, except a right to such treatment as may, at the earliest possible period, fit them for becoming one. The only moral laws for the relation between a civilized and a barbarous government, are the universal rules of morality between man and man'. ${ }^{113}$

In 'Vindication' Mill states that '[s]o long, indeed, as a people are incapable of self-government, it is often better for them to be under the despotism of foreigners than of natives, when those foreigners are more advanced in civilization and cultivation than themselves'. ${ }^{114}$

But then to his credit he adds the following: 'But when their hour of freedom ... has struck, without their having become merged and blended in the nationality of their conquerors, the re-conquest of their own is often an indispensable condition either to obtaining free institutions, or ... of working them in the spirit of freedom'. ${ }^{115}$

One can easily draw the conclusion that Mill, like the great majority of his contemporaries, several liberals included, was an imperialist and a however subtle apologist for conquest and colonialism, a prime example of 'imperial liberalism' ${ }^{116}$ or 'liberal imperialism'. ${ }^{117}$ In our days he is regarded, deservedly, as 'an undisputed spokesperson for British imperialism' ${ }^{118}$ presenting perhaps 'the most well-known liberal justification of empire' and 'ethical framework of imperialism. ${ }^{119}$ Undoubtedly Mill was no critic of empire or of imperialism (contrary to other liberals of his time, such as Richard Cobden, John Bright or Herbert Spencer, who tended to follow the anti-colonial tradition of Jeremy Bentham). Upon closer scrutiny however terms such as 'benign imperialism' or 'benign colonialism, ${ }^{120}$ or 'tolerant imperialism" ${ }^{121}$ are perhaps more appropriate and in this way one also avoids retrospective thinking. Let us see why.

Firstly Mill was following, as we have said, the dominant spirit of the time that resonated even among several liberals, a case in point being his friend and co-liberal across the Channel, Alexis de Tocqueville, an apologist of the French conquest of Algeria (which Mill also endorsed) on similar grounds to those of Mill. Secondly when faced with what appeared cruel and 'uncivilized' traditions, such as the sutee in India, his response was that only by teaching them otherwise would they stop such inhuman practices. As Mark Tunick has put it, 'the imperialism Mill defends is not self-interested but beneficent, not self-aggrandizing but reluctant'. ${ }^{122}$ He was mainly in the business of what Michael Doyle has called 'educative imperialism', which did not include conversion to Christianity or the adoption of the culture of the metropolitan state, in this case British culture so as to become civilized. ${ }^{123}$ Thirdly, he often criticized the harsh colonial measures in India (or nearer at home, in Ireland) and was not supportive of narrow British self-interests in India or elsewhere. In British India he advocated the participation of Indians at the highest echelons of the administration. ${ }^{124}$ Fourthly, Mill was not a blatant racist; by today's standards he was a racist 'of a milder sort than that of many of his contemporaries'. ${ }^{125}$ For him cultural differences were not innate but the result of upbringing and circumstances. ${ }^{126}$ True he did use 'race' and 'national character' for these concepts were in vogue in the nineteenth century, but argued that all human 'races' and peoples could move ahead through progress, become nations and attain the highest level now to be found among Europeans and Americans. As he had put it, 'of all vulgar modes of escaping from the consideration of the effect of social and moral influences on the human mind, the most vulgar is that of attributing the diversities of conduct and character to inherent natural differences'. ${ }^{127}$ In fact Mill was criticized by the racists of his time for not endorsing their views and, for his part, he was highly critical of the views of his friend Thomas Carlyle (who claimed that 'Negroes' are born slaves while the white race is 'wiser'). ${ }^{128}$

A second possible exception to non-intervention is resistance to the aggression of 'barbarous neighbours' ${ }^{129}$ This can be seen as an appendage to the previous case, the obvious historical example being the Romans and their barbarian neighbours. But it could also be seen as self-standing, with 'barbarous neighbours' actual neighbours who are aggressive. ${ }^{130}$ Michael Levin points out that Mill had in mind the native states of India (the states not initially incorporated into British India), thereby providing further ground for conquering them. ${ }^{131}$ But it can also be associated with legitimate self- 
defence, ${ }^{132}$ as seen by the following phrase of Mill: 'We must accept, of course, any case in which such assistance is a measure of legitimate self-defense'. ${ }^{133}$ And in 'The Spanish Question', he says that 'self-defence justifies much' ${ }^{134}$ In On Liberty he is more explicit: 'the sole end for which mankind are [sic] warranted, individually or collectively, in interfering with the liberty of action of any of their number, is self-protection'. ${ }^{135}$

A third exception which is more than clear, is military assistance to a national liberation movement if it is 'unable to contend successfully ... against the military strength of another nation much more powerful'. ${ }^{136}$

But a fourth related exception comes to muddy the waters, seemingly linking national freedom with counter-intervention. In the case of the initially successful Hungarian revolution which was later subdued by the Russian army assisting the Austrians, Mill asserts that 'it would have been an honourable and virtuous act on the part of England to have declared that this should not be, and that if Russia gave assistance to the wrong side, England would aid the right'. ${ }^{137}$

Obviously he hesitated when faced with the Hungarian uprising. ${ }^{138}$ Here one is faced with a dilemma. If 'A Few Words' is to be regarded as Mill's last and definite word on this question, then one is left with his hesitation and could agree with Walzer's first reading of Mill: that the two go together, assistance to a secessionist movement cum counter-intervention, ${ }^{139}$ and that intervention is warranted only when counter-revolution by an external party has taken place. ${ }^{140}$ Another option is not to prioritize 'A Few Words' but to attach equal weight to 'Vindication' where he calls for intervening in support of those fighting to prevent them 'from being crushed and trampled' by foreign conquerors. ${ }^{141}$

In support of the first option (counter-intervention), it is worth referring to what was understood at the time by the readers and commentators of 'A Few Words'. As Georgios Varouxakis has pointed out, all of them understood Mill to mean that intervention is exceptional and that one assists a liberation moment if another state has intervened to suppress its efforts, and apparently Mill was content with this interpretation of his views. ${ }^{142}$ It is also worth noting that two other famous liberal contemporaries of Mill, both of them residing in London, and both his interlocutors, Richard Cobden (a strict noninterventionist) and Giuseppe Mazzini were supportive of counter-intervention to offset a previous military intervention (in Mazzini's case in liberation struggles). ${ }^{143}$

As for the second option (intervention to rescue a national liberation movement, and not as counterintervention), in 1865, when Mill was campaigning for elections as a candidate of the Liberal Party, he gave the clear impression that his supported intervention even without counter-intervention. ${ }^{144}$ And Mill's overall thrust regarding nationality ${ }^{145}$ can also be brought in to buttress intervening in support of independence movements irrespective of previous intervention. Mill (like his friend Mazzini) believed that democracy can function properly only in national states. This was the very opposite of the position taken by his contemporary Lord Acton, who was of the view that national states lead to absolutism and discrimination against minorities within. ${ }^{146}$

The fifth exception includes humanitarian intervention. ${ }^{147}$ According to Mill: ${ }^{148}$

A case requiring consideration is that of a protracted civil war, in which the contending parties are so equally balanced that there is no probability of a speedy issue; or if there is, the victorious side cannot hope to keep down the vanquished but by severities repugnant to humanity, and injurious to the permanent welfare of the country. In this exceptional case it seems now to be an admitted doctrine, that the neighbouring nations, or one powerful neighbour with the acquiescence of the rest, are warranted in demanding that the contest shall cease, and reconciliation take place on equitable terms of compromise [emphasis added].

In 'A Few Words' two things are not very clear: (a) does he mean military intervention or only peaceful mediation for a cease-fire and settlement of the conflict? And (b) it is not clear whether he means only struggles against 'native tyrants' or struggles against 'alien rule' as well? But the examples he provides are suggestive, such as the 1827 battle of Navarino by Britain, France and Russia against the Ottomans during the Greek War of Independence. Mill is clearer in 'Vindication': 'to settle among themselves what they consider reasonable terms of accommodation, and if these are not accepted, to interfere by force, and compel the recusant party to submit to the mandate'. ${ }^{149}$ So it seems to me both dyads are included: non-military as well as military intervention, and both types of struggle. 
More generally, regarding the intervention/intervention nexus, it would seem that Mill, in his two earlier works, was tilting more towards intervention, but by 1858, as an older and more prudent man, he had his doubts, thus his views come out as they do, perplexing and tentative.

\section{Concluding Remarks: The Relevance of Kant and Mill}

Let us conclude by pinpointing the lasting contributions of Kant and Mill on the subject discussed that are also of relevance in today's world society and its concerns.

Kant's lasting and still relevant contribution to non-intervention/intervention and related themes is fourfold. First of all is his support for non-intervention as a fundamental principle for peace and security. Second is his sole exception, anarchy in a state, with rival groups fighting each other, each one claiming sovereign authority, for he did not want to open a Pandora box for various forms of armed or other interventions that would render a state's autonomy and independence dead letter. Third is the call that all states become 'republican' (democratic in later-day parlance) and by the same token peaceful internationally, what is known today and studied as 'democratic peace theory'. ${ }^{150}$ And fourthly he was a pioneer of the idea of international human rights, namely that other peoples and states had a responsibility to be concerned with the violation of human rights in other countries, implying peaceful, and not violent initiatives (not intervention per se) aimed at the amelioration of the lot of citizens in foreign lands.

Mill, as we have seen, had much more to say on non-intervention/intervention. First of all, his rule of thumb, that intervention is permissible or perhaps necessary if a wide-spread movement seeks freedom and independence from 'a foreign yoke', but it is not permissible if the aim is to overthrow a 'native tyrant', retains its relevance and can be seen in the approach of supporters of an exceptional right to unilateral (secessionist) self-determination cum external support, if certain criteria are met (discrimination, being in a state of an internal colony and so on). Classical civil wars on the other hand in which a tyrannical government is challenged by the people, could be better served if left to their own devices, to achieve the aim of freedom (a democratic system of government), without external military aid, even though this may boil down to 'survival of the fittest'. Among the some five reasons for non-intervention advanced by Mill, of considerable weight are two of them, at least to my mind as a student of intervention and secessionist wars: uncertainty as to the outcome of a foreign military intervention ('there can seldom be anything approaching to assurance that intervention, even if successful, would be for the good of the people themselves'); that having achieved freedom (a liberal constitution and free democratic rule in a previously autocratic state) solely by one's own efforts, by one's own 'brave labour and danger' (irrespective of whether requesting a foreign saviour is a solecism or not) is bound to render the outcome more stable and self-standing, less likely to lapse into yet another tyrannical rule, not least because people become attached to the things for which they have suffered and made considerable sacrifices.

When it comes to intervention of particular relevance today are the following: the previously mentioned struggles against a foreign yoke (in today's setting support for secessionist movements with a good case); so as to offset a previous intervention by an external party against a people fighting for freedom against foreign rule (counter-intervention); and 'severities repugnant to humanity, and injurious to the permanent welfare of the country' in the course of a protracted civil war or separatist war, that is in effect umanitarian intervention. The latter, humanitarian intervention, is of particular relevance today (from 1971 and especially from 1990 until today) which has led to a heated debate, with as many advocates as opponents.

On the whole Mills stance of supplying convincing arguments for non-intervention and equally convincing ones for intervention may appear confusing, contradictory or even schizophrenic. But perhaps it is better this way and shows the agonizing dilemma involved until this very day: a very credible case against intervening can be made as well as an equally plausible case for intervening in humanitarian plights, internal wars or separatist conflicts. Even if one (a government, intergovernmental organization or scholar) tries to follow a case by case approach it may be hairsplitting to decide, in a specific case, which is more advisable, effective, humane and just. Obviously the safest strategy if we are not faced with egregious crimes (genocide, crimes against humanity and so on) is to provide for peaceful intervention to end the killings (a cease-fire), to provide for a peacekeeping force or if need be some coercive measure short of armed intrusion (blockade, no-flight and some others). 
Table I. J.S. Mill's Exceptions to Non-Intervention

Miller $1961^{151}$

1. If liberty is interfered by other powers

2. In civil wars with severities repugnant to humanity

3. In the affairs of backward or barbaric peoples

4. In the name of self-protection

5. Assistance by any liberal government in support of struggles in Europe for national liberation

Holbraad $1970^{152}$

1. Armed support for a nation fighting foreign conquerors (not to allow the nation to be crushed by tyrannical oppressors)

2. Long civil wars where the outcome may be decided by consequences repugnant to humanity (the aim: reasonable terms of accommodation) or put differently, 'to stop mischief and benefit humanity'

Vincent $1974^{153}$

1. Barbarians

2. Protracted civil war in order to end it (humanitarian intervention)

3. Assistance to a people kept down by foreign intervention (counter-intervention)

Walzer $1977^{154}$

1. Assistance to a secessionist movement (tendency to take it together with counter-intervention)

2. Counter-intervention

3. Barbarians can be conquered

Beitz $1979^{155}$

1. For the benefit of the barbarous nations

2. In support of a free people struggling against a foreign yoke

3. To offset other external interference

Ellis, $1992^{156}$

1. Intervention in the affairs of an uncivilized people and this to its interest

2. If the government has received external help

Laberge $1995^{157}$

1. Barbarians to their own benefit

2. To support a people struggling 'against their government for free institutions' and liberty (foreign yoke)

3. In instances of 'counterintervention' in support of a people 'in arms for liberty'

Ramsbotham and Woodhouse $1996^{158}$

1. National liberation

2. Counter-intervention

3. Protracted civil war with no prospect of restoring order

4. Barbarians because normal reciprocity does not apply

Varouxakis $1997^{159}$

1. Military aid to a nation attempting to free itself from a foreign yoke

2. Against counter-revolution, to enforce non-intervention

3. Involvement in protracted civil wars, the aim being accommodation, but if accommodation not accepted use of force against "the recusant party"

4. In protracted civil war, in case of acts repugnant to humanity ('humanitarian intervention')

Parekh $1997^{160}$ 

Mill

1. To stop the intervention of others

2. In protracted civil war when neither party is winning

3. To prevent international disorder

Prager $2005^{161}$

1. To counter counter-intervention

2. When widespread atrocities have been committed

3. Prolonged civil war to reduce suffering

4. Neighbour's barbarous practices

Miller $2005^{162}$

1. To overthrow a foreign oppressor

2. As regards barbarians

Walzer $2007^{163}$

1. In cases of barbarism

2. Protracted civil war: need to stop the fighting and impose a compromise

3. In support of a national liberation struggle (yoke by foreigners) but not in support of a revolutionary struggle

Doyle $2009^{164}$

1. Legitimate self-defense

2. Post-war standing menace

3. Forcible mediation in protracted civil war

4. Self-determination/secession

5. Counter-intervention

6. Humanitarian intervention

7. Benign imperialism

Jahn $2012^{165}$

1. Protracted civil wars

2. Severities repugnant to humanity

3. Counter-intervention

Heraclides and Dialla $2015^{166}$

1. Relations with 'barbarians'

2. Offsetting previous counter-revolution by an external party against a people fighting against foreign rule

3. Struggles against a foreign yoke

4. Protracted civil wars

5. Severities repugnant to humanity (humanitarian intervention). 


\section{REFERENCES}

[1] S. D. Krasner, Sovereignty and Intervention, in G. M. Lyons and M. Mastanduno (eds), Beyond Westphalia? State Sovereignty and International Intervention, Baltimore, USA: Johns Hopkins University Press, 1995, pp. 235-6.

[2] R. Jackson, Sovereignty in World Politics: A Glance at the Conceptual and Historical Landscape, Political Studies, 47(3) (1999), p. 439.

[3] M. Wight, Western Values in International Relations', in H. Butterfield and M. Wight (eds), Diplomatic Investigations: Essays in the Theory of International Politics, London, UK: Allen and Unwin, 1966, p. 113; J.R. Vincent, Nonintervention and International Order, Princeton, USA: Princeton University Press, 1974, p. 27.

[4] Winfield, P. H., The History of Intervention in International Law, British Yearbook of International Law, 3 (1922-1923), p. 135.

[5] Ibid., pp. 130, 135-6, 141.

[6] Calvo, C., Le droit internationale: théorie et pratique, Paris, France: Guillaumin et Cie, G. Pedone-Lauriel, 1880, $3^{\text {rd }}$ edition [1870], p. 237, paragraph 134. Our translation from the French.

[7] Winfield, The History of Intervention in International Law, p. 130.

[8] See Fenwick, C. G., Intervention: Individual and Collective, American Journal of International Law, 39 (4) (1945), pp. 645-51; Rosenau, J. N., The Concept of Intervention, Journal of International Affairs, 22 (2) (1968), pp.165-76; Little, R., Intervention: External Involvement in Civil Wars, London, UK: Robert Robertson, 1975; Beitz, C.R., Political Theory and International Relations, Princeton, USA: Princeton University Press, 1979, pp. 71-92.

[9] See e.g. Macmillan, J., Intervention and the Ordering of the Modern World', Review of International Studies, 39 (2013), pp. 1039-56; Reus-Smit, C., The Concept of Intervention, Review of International Studies, 39 (2013), pp.1057-76.

[10] See e.g. S. Hoffmann et al. eds, The Ethics and Politics of Humanitarian Intervention, Notre Dame, USA: University of Notre Dame Press, 1996; O. Ramsbotham and T. Woodhouse, Humanitarian Intervention: A Reconceptualization, Cambridge, UK: Polity Press, 1996; TÉ

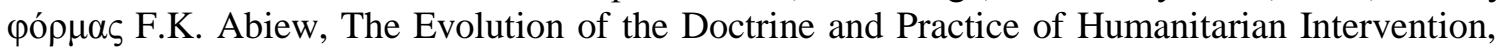
The Hague, Netherlands: Kluwer Law International, 1999; N.J. Wheeler, Saving Strangers. Humanitarian Intervention in International Society, Oxford, UK: Oxford University Press, 2000; S. Chesterman, Just War or Just Peace? Humanitarian Intervention and International Law, Oxford, UK: Oxford University Press, 2001; A. Orford, Reading Humanitarian Intervention: Human Rights and the Use of Force in International Law, Cambridge, UK: Cambridge University Press, 2003); J.L. Holzgrefe and R.O. Keohane, eds, Humanitarian Intervention: Ethical, Legal, and Political Dilemmas, Cambridge, UK: Cambridge University Press, 2003; T. Nardin and M.S. Williams, eds, Humanitarian Intervention, New York, USA: New York University Press, 2006.

[11] H. Bull, Introduction, in H. Bull ed., Intervention in World Politics, Oxford, UK: Clarendon Press, 1984, p. 1; R. Higgins, Intervention and International Law, in ibid., pp. 30-2.

[12] L. Oppenheim, International Law: A Treatise, $5^{\text {th }}$ edition, edited by H. Lauterpacht, London, UK: Longmans, Greene and Co., 1937) [1905], vol.I, p. 249.

[13] Winfield, The History of Intervention in International Law, p. 139.

[14] Vincent, Nonintervention and International Order, p. 30.

[15] See A. Heraclides and A. Dialla, Humanitarian Intervention in the Long Nineteenth Century: Setting the Precedent, Manchester, UK: Manchester University Press, 2015, pp. 71-2.

[16] 1 Little, Intervention, p.18.

[17] Quoted in Wight, Western Values in International Relations, p. 115.

[18] Garner, J.W., Recognition of Belligerency, American Journal of International Law, 32(1) (1938), pp. 106-13; R.A. Falk, 'Janus Tormented: The International Law of Internal Law', in J. N. Rosenau ed., International Aspects of Civil Strife, Princeton, USA: Princeton University Press, 1964, pp. 194-209. 
[19] Garner, 'Recognition of Belligerency', pp. 111-13.

[20] H. Temperley, The Foreign Policy of Canning 1822-1827, London: Frank Cass, 1966), [1925], pp. 326-7.

[21] J.L. Offner, An Unwanted War: The Diplomacy of the United States and Spain over Cuba, Chapel Hill, USA: University of North Carolina Press, 1992, pp. 181-4.

[22] Heraclides and Dialla, Humanitarian Intervention in the Long Nineteenth Century, pp. 57-80.

[23] Laberge, P., Humanitarian Intervention: Three Ethical Positions, Ethics and International Affairs, 9 (1995), p.15.

[24] M. Hoffman, Normative International Theory: Approaches and Issues, in A.J.R. Groom and M. Light eds, Contemporary International Relations: A Guide to Theory, London, UK: Pinter Publisher, 1994, pp. 31-5.

[25] Conway, S., Bentham on Peace and War, Utilitas, 1(1) (1989), pp. 88-98.

[26] K. Robbins, Richard Cobden: The International Man, in A. Howe and S. Morgan eds, Rethinking Nineteenth-Century Liberalism: Richard Cobden. Bicentenary Essays, Aldershot, UK: Ashgate, 2006, pp. 177-88.

[27] R.J. Vincent, Nonintervention and International Order, Princeton, USA: Princeton University Press, 1974, p. 46.

[28] C. Brown, International Relations Theory: New Normative Approaches, London, UK: Harvester Wheatsheaf, 1992, p. 71.

[29] Ibid., p. 65.

[30] Tesón, F., Humanitarian Intervention: An Inquiry into Law and Morality, New York, USA: Transnational Publishers, 1997 [1988]), p. 55.

[31] H. Bull, The Anarchical Society: A Study of Order in World Politics, New York, USA: Columbia University Press, 1977, pp. 25-6; T. Donaldson, 'Kant's Global Rationalism', in T. Nardin and D.R. Mapel eds, Traditions of International Ethics, Cambridge, UK: Cambridge University Press, 1992, pp. 143-4.

[32] I mention this for in fact Kant did succumb to racism in his early 'pre-critical' days in the 1760s, as regards 'the Negroes of Africa', swayed by a remark on the part of David Hume that they are 'naturally inferior to the whites'. He continued in this vein in the 1780 s with reference to 'Americans and Negroes', asserting that they 'cannot govern themselves'. This racism changed drastically in the last fifteen years of his life where the word 'race' disappeared completely from his writings and he came out against all forms of domination of one human group by another, against slavery and against European colonialism. See A. Pagden, The Enlightenment and Why it Still Matters, New York, USA: Random House, 2013, pp. 167-8.

[33] For a more nuanced view regarding Kant's cosmopolitanism, see F.H. Hinsley, Power and the Pursuit of Peace, Cambridge, UK: Cambridge University Press, 1963, pp. 62-80; Hurrell, A., Kant and the Kantian Paradigm in International Relations, Review of International Studies, 16(3) (1990), pp. 183-205.

[34] For a succinct presentation of the points raised by Kant in Perpetual Peace, see Williams, H.L., Back from the USSR: Kant, Kaliningrad and World Peace, International Relations, 20(1) (2006), pp. 27-48.

[35] I. Kant, Toward Perpetual Peace, in I. Kant, Practical Philosophy, Cambridge, UK: Cambridge University Press, 1996, p. 319.

[36] Ibid., pp. 319-20.

[37] Ibid., pp. 319-20.

[38] Williams, Back from the USSR, p. 37.

[39] Tesón, F.R., The Kantian Theory of International Law, Columbia Law Review, 92(1) (1992), pp. 67-8; Laberge, Humanitarian Intervention, p. 18. 
[40] See Axinn, S., Kant, Authority, and the French Revolution, Journal of the History of Ideas, 32(3) (1971), pp. 179-92; Beck, L. W., Kant and the Right of Revolution, Journal of the History of Ideas, 32(3) (1971), pp. 411-22; Reiss, H. S., Kant and the Right of Rebellion, Journal of the History of Ideas, 17(2) (1956), pp. 179-92.

[41] Mertens, T., War and International Order in Kant's Legal Thought, Ratio Juris, 8(3) (1995), p. 31 fn.14; H. van der Linden, Kant: The Duty to Promote International Peace and Political Intervention', Proceedings of the Eighth International Kant Congress, Memphis 1995, vol.II, Milwaukee, USA: Marquette University Press, 1995, p. 73; Franceschet, A., Kant, International Law, and the Problem of Humanitarian Intervention, Journal of International Political Theory, 6(1) (2010), p. 8; Williams, Back from the USSR, pp. 31, 37-8.

[42] Laberge, Humanitarian Intervention, p. 18.

[43] Both quotes in Orend, B., 'Kant's Ethics of War and Peace, Journal of Military Ethics, 3(2) (2004), p. 163.

[44] Quoted in Hurrell, Kant and the Kantian Paradigm in International Relations, p. 201.

[45] For Kant's complex position on war, see Orend, B., Kant's Just War Theory, Journal of the History of Philosophy, 37(2) (1999), pp. 323-53; Orend, Kant's Ethics of War and Peace, pp. 161-97; Pagden, The Enlightenment and Why it Still Matters, pp. 348-9. For Kant as a pacifist, see Mertens, War and International Order in Kant's Legal Thought, pp. 296-314.

[46] Axinn, Kant, Authority, and the French Revolution, p. 425.

[47] Mertens, War and International Order in Kant's Legal Thought, p. 304; R. Tuck, The Rights of War and Peace: Political Thought and the International Order from Grotius to Kant, Oxford, UK: Oxford University Press, 1999, pp. 217-18.

[48] Orend, Kant's Ethics of War and Peace, pp. 167-9.

[49] Mertens, War and International Order in Kant's Legal Thought, p. 311; Mertens, T., Kant's Cosmopolitan Values and Supreme Emergencies, Journal of Social Philosophy, 38(2) (2007), p. 227; Hurrell, Kant and the Kantian Paradigm in International Relations, pp. 200-2; H. Williams, Kant and the End of War: A Critique of Just War Theory, Basingstoke, UK: Palgrave Macmillan, 2012, pp. 32, 130, 135.

[50] See Mertens, Kant's Cosmopolitan Values and Supreme Emergencies, pp. 225-7; Reichberg, G., Just War or Perpetual Peace?, Journal of Military Ethics, 1(1) (2002), 30; Hurrell, Kant and the Kantian Paradigm in International Relations, pp. 200-2; Orend, Kant's Ethics of War and Peace, p. 169.

[51] See Cavallar, G., Commentary on Susan Meld Shell's 'Kant on Just War and "Unjust Enemies": Reflections on a "Pleonasm", Kantian Review, 11 (2006), pp. 117-24; Van der Linden, 'Kant', pp. 73-4.

[52] See below footnotes 53-63 and the following: Bagnoli, C., Humanitarian Intervention as a Perfect Duty: A Kantian Argument, Nomos, 47 (2004), pp. 1-29; Shell, S. M., Kant on Just War and 'Unjust Enemies': Reflections on a 'Pleonasm', Kantian Review, 10 (2005), pp. 82-111; Bernstein, A. R., Kant on Rights and Coercion in International Law: Implications for Humanitarian Intervention, Jahrbuch für Recht und Ethik/Annual Review of Law and Ethics, 16 (2008), pp. 57-100.

[53] Tesón, F.R., The Kantian Theory of International Law, Columbia Law Review, 92(1) (1992), pp. 54, 60-2, 67, 69-70.

[54] C.R. Beitz, Political Theory and International Relations, Princeton, USA: Princeton University Press, 1979, p. 82.

[55] Vincent, Nonintervention and International Order, p. 57.

[56] Tesón, The Kantian Theory of International Law, p. 92.

[57] Ibid., p. 93. See also Lillich, R.B., Kant and the Current Debate over Humanitarian Intervention, Journal of Transnational Law and Policy, 6 (1997), p. 397.

[58] Van der Linden, Kant, pp. 73-4.

[59] Hill, T., Kant and Humanitarian Intervention, Philosophical Perspectives, 23 (2009), p. 229. 
[60] Ibid., p. 236.

[61] Franceschet, Kant, International Law, and the Problem of Humanitarian Intervention, p. 4.

[62] Ibid., p. 8.

[63] Ibid., pp. 8-18.

[64] See on this basic point Laberge, Humanitarian Intervention, p. 18.

[65] Beitz, Political Theory and International Relations, p. 82 fn.35.

[66] Williams, Kant and the End of War, p. 118.

[67] Laberge, Humanitarian Intervention, p. 18.

[68] Hampsher-Monk, I., Edmund Burke's Changing Justification for Intervention, Historical Journal, 48(1) (2005), pp. 66-8.

[69] Pagden, A., Stoicism, Cosmopolitanism, and the Legacy of European Imperialism, Constellations, 7(1) (2000), p. 18.

[70] Laberge, Humanitarian Intervention', p. 18.

[71] Cavallar, Commentary on Susan Meld Shell's 'Kant on Just War and "Unjust Enemies", p. 121.

[72] Franceschet, Kant, International Law, and the Problem of Humanitarian Intervention, p. 11.

[73] Williams, Kant and the End of War, p. 140. On this point see also Donaldson, Kant's Global Rationalism, pp. 142-6.

[74] Williams, Kant and the End of War, p. 130.

[75] Ibid., pp. 131, 133.

[76] Brown, International Relations Theory, 71, 73-5; Hoffman, 'Normative International Theory, 33.

[77] See Miller, K. E., John Stuart Mill's Theory of International Relations', Journal of the History of Ideas, 22(4) (1961), pp. 499-501, 504.

[78] Georgios Varouxakis regards Mill an advocate of 'cosmopolitan patriotism' as he calls it. See G. Varouxakis, Cosmopolitan Patriotism in J. S. Mill's Political Thought and Action, in N. Urbinati and A. Zakaras eds, J. S. Mill's Political Thought: A Bicentennial Reassessment, Cambridge, UK: Cambridge University Press, pp. 277-97.

[79] A Few Words on Non-Intervention, Fraser's Magazine, LX (December 1859), reprinted in Mill, Dissertations and Discussions, vol.III, pp. 153-78 [henceforth A Few Words].

[80] A. Ellis, 'Utilitarianism and International Ethics', in Nardin and Mapel eds, Traditions of International Ethics, p. 166.

[81] M. Levin, J. S. Mill on Civilization and Barbarism, London, UK: Routledge, 2004, p. 49.

[82] As it is entitled in Mill, Dissertations and Discussions, vol.II, pp. 335-410 [henceforth Vindication].

[83] Vindication, p. 25.

[84] Art VIII. Spain. The Spanish Question, London and Westminster Review, V(2) (July 1837), pp. 165-94 [henceforth The Spanish Question].

[85] M. Walzer, Mill's 'A Few Words on Non-Intervention': A Commentary, in N. Urbinati and A. Zakaras eds, J.S. Mill's Political Thought: A Bicentennial Reassessment, Cambridge, UK: Cambridge University Press, p. 352.

[86] A Few Words, p. 173.

[87] Beitz, Political Theory and International Relations, pp. 84-6; M. Walzer, 'The Rights of Political Communities', in C.R. Beitz et al, International Ethics, Princeton, USA: Princeton University Press, 1985, pp. 178-9; Ellis, Utilitarianism and International Ethics, pp. 166-7.

[88] Michael Doyle, in a perceptive article on Mill and Walzer, has come up with five points and I have taken on board three of those. See Doyle, M. W. 'A Few Words on Mill, Walzer, and Nonintervention, Ethics and International Affairs, 23 (2009), pp. 352-5.

[89] A Few Words, p. 173. 
[90] Ibid., p. 173.

[91] See Doyle, A Few Words on Mill, Walzer, and Nonintervention, pp. 352-3.

[92] A Few Words, p. 174.

[93] The Spanish Question, p. 179.

[94] A Few Words, p. 174.

[95] Ibid., p. 175.

[96] Ibid., p. 175.

[97] Quoted in M. Deutsch, The Resolution of Conflict, New Haven, USA: Yale University Press, 1973, p. 357.

[98] Ibid., p. 357.

[99] For the sake of accuracy it is worth remembering that 'survival of the fittest' was coined by Herbert Spencer and endorsed by Charles Darwin, but the concept was misunderstood by crude social Darwinists, much to the dismay of Spencer. See Rogers, J.A., Darwinism and Social Darwinism, Journal of the History of Ideas, 33(2) (1972), pp. 265-8, 276-80.

[100] J.N. Moore, 'International Law and the United States' Role in Vietnam: A Reply', in R. Falk ed., The Vietnam War and International Law, Princeton, USA: Princeton University Press, 1968, p. 431.

[101] Walzer, The Rights of Political Communities, p. 179.

[102] A. Ellis, Utilitarianism and International Ethics, in Nardin and Mapel eds, Traditions of International Ethics, p. 167.

[103] For a previous slightly different conclusion on my part, see Heraclides and Dialla in end of Table I.

[104] Among nineteenth century international jurists the Scottish James Lorimer was renowned for this distinction. See Bull, The Anarchical Society, p.38.

[105] Pagden, The Enlightenment and Why it still Matters, pp. 249-50.

[106] See J.S. Mill, 'Civilization', in Dissertations and Discussions, vol.I, p. 160.

[107] Levin, J. S. Mill on Civilization and Barbarism, pp. 31-2, 37.

[108] Ibid., pp. 3, 37, 66, 94-120. This view of stagnation, with China as the prime example, was a widely held view, enlisting, among others, Rousseau, Condorcet, James Mill and among Mill's contemporaries, Leopold von Ranke, Karl Marx and Friedrich Engels. See ibid., pp. 94-7.

[109] A Few Words, pp. 167-8.

[110] Ibid., p. 167.

[111] Ibid., p. 167.

[112] Ibid., p. 168.

[113] Ibid., p. 168.

[114] Vindication, p. 31.

[115] Ibid., p. 31.

[116] J. Pitts, A Turn to Empire: The Rise of Imperial Liberalism in Britain and France, Princeton, USA: Princeton University Press, 2005, pp. 126-52; Levin, J.S. Mill on Civilization and Barbarism, pp. 45-57.

[117] S. Holmes, Making Sense of Liberal Imperialism, in Urbinati and Zakaras eds, J.S. Mill's Political Thought, pp. 319-346.

[118] Tunick, M., Tolerant Imperialism: John Stuart Mill's Defense of British Rule in India, The Review of Politics, 68(4) (2006), p. 586.

[119] K. Mantena, The Crisis of Liberal Imperialism, in D. Bell ed., Victorian Visions of Global Order: Empire and International Relations in Nineteenth-Century Political Thought, Cambridge, UK: Cambridge University Press, 2007, p. 118; See also K. Mantena, Mill and the Imperial Predicament, in Urbinati and Zakaras eds, J. S. Mill's Political Thought, pp. 298-317; Sullivan, E.P., 'Liberalism and Imperialism: J.S. Mill's Defense of the British Empire', Journal of the History of Ideas, 44(4) (1983), pp. 599-617; U.S. Mehta, Liberalism and Empire: A Study in Nineteenth-Century British Liberal Thought, Chicago, USA: University of Chicago Press, 1999, pp. 47-77; Jahn, B., Barbarian Thoughts: Imperialism in the Philosophy of John Stuart Mill, Review of International Studies, 31 (2005), pp. 599-618. 
[120] Doyle, A Few Words on Mill, Walzer, and Nonintervention, pp. 356, 363-5.

[121] Tunick, Tolerant Imperialism, p. 586.

[122] Ibid., p. 591.

[123] Doyle, A Few Words on Mill, Walzer, and Nonintervention, p. 364.

[124] Levin, J.S. Mill on Civilization and Barbarism, p. 41.

[125] Miller, J.J., Forced to be Free: Rethinking J.S. Mill and Intervention, Politics and Ethics Review, 1(2) (2005), p. 121.

[126] See for details Varouxakis, G., John Stuart Mill on Race, Utilitas, 10(1) (1998), pp. 18-32.

[127] Quoted in ibid., p. 23.

[128] Ibid., pp. 22-3, 27.

[129] A Few Words, p. 167.

[130] See Prager, C.A. Intervention and Empire: John Stuart Mill and International Relations, Political Studies, 53 (2005), p. 629.

[131] Levin, J. S. Mill on Civilization and Barbarism, p. 49.

[132] Doyle, A Few Words on Mill, Walzer, and Nonintervention, 355.

[133] Quoted in ibid., p. 355.

[134] The Spanish Question, p. 179.

[135] Quoted in Levin, J.S. Mill on Civilization and Barbarism, p. 507.

[136] A Few Words, p. 176.

[137] A Few Words, pp. 176-7.

[138] For reference to Mill's hesitation at this point see M. Walzer, Just and Unjust War: A Moral Argument with Historical Illustrations, New York, USA: Basic Books, 1977, p. 93; Laberge, Humanitarian Intervention, p. 23; Varouxakis, John Stuart Mill on Intervention and NonIntervention, pp. 70-1.

[139] Walzer, Just and Unjust Wars, p. 90.

[140] G. Varouxakis, Liberty Abroad: J. S. Mill and International Relations, Oxford, UK: Oxford University Press, 2013, p. 90.

[141] Vindication, p. 29.

[142] Varouxakis, Liberty Abroad, pp. 92-4.

[143] On Cobden's view on this issue see Vincent, Nonintervention and International Order, p. 53. On Mazzini's view see his short essay, On Nonintervention, in S. Recchia and N. Urbinatieds, A Cosmopolitanism of Nations: Giuseppe Mazzini's Writing on Democracy, Nation Building and International Relations, Princeton, USA: Princeton University Press, 2009, p. 216.

[144] Varouxakis, Liberty Abroad, p. 97.

[145] See Grader, S., John Stuart Mill's Theory of Nationality: A Liberal Dilemma in the Field of International Relations, Millennium: Journal of International Studies, 14(2) (1985), pp. 207-16; G. Varouxakis, Mill on Nationality, London, UK: Routledge, 2002.

[146] Grader, John Stuart Mill's Theory of Nationality, p. 211.

[147] Several authors regard humanitarian intervention even though subsumed under civil war, as a separate self-standing exception, see Miller, John Stuart Mill's Theory of International Relations, pp. 505, 507, 510; Holbraad, The Concert of Europe, pp. 164-6; Vincent, Nonintervention and International Order, pp. 55-6; Varouxakis, John Stuart Mill on Intervention and Non-Intervention, pp. 59-60, 68-75; Prager, Intervention and Empire, pp. 62930; Doyle, A Few Words on Mill, Walzer, and Nonintervention, pp. 355-64; Jahn, B., Humanitarian Intervention - What's in a Name, International Politics, 49(1) (2012), pp. 51-2; Heraclides and Dialla, Humanitarian Intervention in the Long Nineteenth Century, pp. 90-1.

[148] A Few Words, p. 172.

[149] Vindication, p. 29. 
[150] M.W. Doyle, Liberalism and World Politics Revisited, in C.W. Kegley ed., Controversies in International Relations Theory: Realism and the Neoliberal Challenge, New York, USA: St. Martin's Press, 1995, pp. 83-106. M.E. Brown et al. eds, Debating the Democratic Peace, Cambridge, Mass., USA: The MIT Press, 1996; B. Russett, Grasping the Democratic Peace, Princeton, USA: Princeton University Press, 1993; B. Russett and J. Oneal, Triangulating Peace: Democracy, Interdependence and International Organizations, New York, USA: Norton Series in World Politics, 2011.

[151] Miller, John Stuart Mill's Theory of International Relations, pp. 505, 507, 510.

[152] Holbraad, The Concert of Europe, pp. 164-6.

[153] Vincent, Nonintervention and International Order, pp. 55-6.

[154] Walzer, Just and Unjust War, pp. 90, 93.

[155] Beitz, Political Theory and International Relations, pp. 82, 85.

[156] Ellis, Utilitarianism and International Ethics, pp. 166-7.

[157] Laberge, Humanitarian Intervention, pp. 22-3.

[158] O. Ramsbotham and T. Woodhouse, Humanitarian Intervention: A Reconceptualization Cambridge, UK: Polity Press, 1996, p. 48.

[159] Varouxakis, John Stuart Mill on Intervention and Non-Intervention, pp. 59-60, 68-75.

[160] Parekh, B., Rethinking Humanitarian Intervention, International Political Science Review, 18(1) (1997), p. 52.

[161] Prager, Intervention and Empire, pp. 629-30.

[162] Miller, Forced to be Free, pp. 121-2.

[163] Walzer, Mill's ‘A Few Words on Non-Intervention', pp. 350-3.

[164] Doyle, A Few Words on Mill, Walzer, and Nonintervention, pp. 355-64.

[165] Jahn, Humanitarian Intervention - What's in a Name, pp. 51-2.

[166] Heraclides and Dialla, Humanitarian Intervention in the Long Nineteenth Century, pp. 89-91. 